\title{
A POESIA BRASILEIRA LIDA NUMA \\ ANTOLOGIA: EXERCÍCIOS DE SOLIDÃO
}

\section{BRAZILIAN POETRY READ IN AN ANTHOLOGY: LONELINESS PRACTICES}

Wilberth SALGUEIRO ${ }^{1}$

RESUMO: O livro Antologia comentada da poesia brasileira do século 21 reúne 205 poemas de 70 poetas. Embora haja obras anteriores ao ano 2000, a maioria dos poemas selecionados foi publicada em livros já do século 21 . A coletânea se propõe, com bastante eficácia, a mostrar "tendências do presente e de um futuro imediato". O panorama explicita, entre outros aspectos, (a) a convivência de gerações, (b) a hegemonia da metapoesia, (c) a força do cotidiano particular e (d) a eleição da cidade como espaço de sedução e errância; mas evidencia também a escassez de poemas e poetas interessados em questões eminentemente sociais, políticas, coletivas. Sobressai, no conjunto, uma estética de efeitos — ensimesmados, autotélicos.

PALAVRAS-CHAVE: Poesia brasileira. Antologia comentada da poesia brasileira do século 21. Manuel da Costa Pinto.

ABSTRACT: The book "Antologia comentada da poesia brasileira do século 21" is a compilation of 205 poems of seventy poets. Even though there are works that were written before the year 2000, most of the selected poems were published in 21st century books. This collection has the efficient purpose of showing "the present tendencies and the immediate future"of poetry. This overview turns clear the aspects of: (a) the poetry generations coexistence, (b) the metapoetry hegemony, (c) the private daily life power and (d) the choice of

${ }^{1}$ Departamento de Línguas e Letras, Universidade Federal do Espírito Santo, Vitória / ES, wilberthcfs@gmail.com 
the city as a place for seduction and wanderingness. However, it also highlights the shortage of poems and the poets' interested in affairs which are eminently social, political and collective. Therefore, the most important aspect is the aesthetic of effects which is enclosed and autotelic.

KEYWORDS: Brazilian poetry. Antologia comentada da poesia brasileira do século 21. Manuel da Costa Pinto.

\section{Introdução}

Antes de publicar Antologia comentada da poesia brasileira do século 21 (Pinto, 2006), o jornalista Manuel da Costa Pinto havia lançado, em 2004, também pela Publifolha, o livro Literatura brasileira hoje (integrante da exitosa série "Folha explica”), uma espécie de preparação para esta antologia. Afinal, 29 dos 30 poetas que lá estavam, no livro de 2004, em capítulos próprios, retornam no livro de $2006^{2}$. São livros, na verdade, complementares - embora autônomos - , que pretendem esboçar de forma objetiva, e supostamente inclusiva, uma historiografia das nossas letras recentes.

Figura constante na mídia impressa e televisiva, envolvido em grandes atividades culturais (Tv Cultura, Flip, Prêmio Telecom, Itaú Cultural, Revista Cult, Feira de Frankfurt etc.), mestre em Teoria literária pela USP, autor de livro sobre Albert Camus, o antologista sabe ser, literalmente, impossível uma antologia do século 21 no ano de 2006. Por isso, a primeira frase da "Apresentação" diz: "O título desta antologia pode parecer uma ironia. É e não é” (p. 9). Logo acima da frase, uma epígrafe, de Sérgio Milliet - "A compreensão do fenômeno artístico não implica a aprovação irrestrita dos resultados" —, parece, ironicamente, se referir à própria composição da antologia, que, como toda e qualquer antologia, provoca polêmicas e, em geral, um coro de insatisfeitos.

Após expor alguns critérios, entre os quais o de incluir "apenas autores que publicaram poesia nesse início de século 21”, justificando assim

${ }^{2}$ A exceção fica por conta de Bruno Tolentino, "que não autorizou a publicação de seus poemas" (p. 13). 
ausências como as de Hilda Hilst e Décio Pignatari, o organizador afirma, com ingenuidade ou jogo de cena, que "a intenção desta antologia não é propor juízos de valor. (...) ao contrário, é detectar as razões pelas quais esses poetas conquistaram um espaço na cena literária brasileira": ora, selecionar obras e autores para uma antologia já é acionar juízos de valor; ademais, uma antologia não "detecta" as razões por que poetas adquirem visibilidade - ela expande e legitima essa visibilidade. A seleção dos poetas e dos poemas diz, é claro, do gosto, dos afetos e dos valores do antologista. É isso mesmo que sustenta Elisa Tonon: "Se, como afirmam os discursos que acompanham as antologias, não se pode estabelecer características unívocas à produção poética que reúnem, por outro lado é possível detectar uma atitude crítica comum na própria constituição do objeto-antologia" (TONON, 2012). Em suma, um leitor atento e cético não deve jamais perder de vista o óbvio: que uma antologia é uma escolha subjetiva e, portanto, incorpora - e não pode ser de outro jeito - os limites intrínsecos ao gesto.

Diga-se, desde já, que, embora breves, e mesmo por isso, os comentários de Costa Pinto são bem objetivos, pontuais e, em regra, precisos - em que pese a excessiva generosidade com o conjunto de poemas e autores. Isso posto, entre os 70 nomes e 205 poemas da antologia, transitam aspectos, temas e estilos, como é previsível, os mais díspares. Todavia, é possível assinalar alguns tópicos e recursos mais recorrentes, que dirá, ao mesmo tempo, como vimos, tanto da poesia coligida quanto do coligidor: no conjunto, sobretudo, dará um quadro ampliado do cenário contemporâneo de nossa poesia.

\section{Gerações}

Ressalta na antologia o convívio de gerações: Affonso Ávila, Manoel de Barros, Augusto de Campos, Haroldo de Campos, Mário Chamie, Ferreira Gullar, Armando Freitas Filho, Adélia Prado, Waly Salomão e Caetano Veloso se avizinham de poetas jovens e com pouca, ou crescente, 
visibilidade no circuito da poesia. Nota-se que os poemas destes poetas mais experientes, em geral, além de mais densos, procuram elaborar reflexões que articulam de forma rigorosa os extratos sonoros, imagéticos e semânticos (para lembrar terminologia poundiana, adotada pelos concretos: extratos melofanologopaicos).

Valham como exemplos as complexas construções que Caetano engendra nos três poemas-canções da antologia: "Tropicália”, "Fora da ordem" e "Livros", respectivamente de 1968 (Caetano Veloso), 1991 (Circuladô) e 1997 (Livro). Ou os também três poemas estampados de Augusto de Campos, plenos de nuances e sugestões que atiçam a inteligência do leitor: "cidade/city/cité" (Vivavaia, 1979), “ad marginem” e "sub” (ambos de Não, 2003).

\section{Hermetismo}

Confirmando um traço da poesia recente, os mais jovens muitas vezes optam por construções em que prevalecem ora jogos meramente fônicos, ora calcadas em metáforas indecodificáveis, ora ainda em elucubrações sem quaisquer referentes para o leitor ensaiar alguma possível leitura. Não se trata, é óbvio, de defender poéticas de fácil entendimento. Há, entretanto, uma tendência de se elaborarem - e publicarem - poemas para cuja compreensão seria necessário ter informações privilegiadas, às vezes mesmo de dados biográficos. Se o sentido, ou sentidos, de um poema depende de o leitor ter tal ou qual informação, então, definitivamente, o poema será para poucos, pouquíssimos leitores.

Em comentário a poemas de Age de Carvalho e de Carlito Azevedo, Costa Pinto falará sobre o assunto: "sua poesia [de Age] ao mesmo tempo hermética (conteúdos de difícil entendimento, que só a muito custo conseguem emergir à consciência) e límpida" (p. 127); "escrita [de Carlito] que se alimenta de referências textuais e estéticas do alto modernismo e que tem uma propensão para o hermetismo, para a expressão de conteúdos incomunicáveis (característica de boa parte da poesia 
moderna, que explora a dissonância entre a limpidez da expressão e as relações lógicas inusitadas" (p. 55). Sendo a elipse aquilo que falta, não à toa será uma figura de linguagem recorrente em grande parte da obra de muitos poetas.

\section{Metapoesia}

Outra verificação evidente é a imensa quantidade de poemas explicitamente metapoéticos, veio que, parece, não se exaure jamais. Na melhor das hipóteses, o mais comum é que esses poemas autorreferentes se vinculem à problemática existencial - do estar no mundo: nesse sentido, pensar o poema seria uma espécie de metonímia do pensar-se como sujeito.

Esse exercício obsessivo em torno do próprio fazer do poema - normalmente considerado um objeto intransitivo, para deleite e prazer, sem fim que não a própria feitura e existência - constitui sem dúvida uma longuíssima tradição. Por isso mesmo, para além de um gesto onanístico individual, ele implica um movimento de emulação à tradição. Cada período se manifesta de certa maneira. Um risco - se não um propósito - é a tendência de tais exercícios obliterarem, nessas encenações, a potência da história humana, em especial suas dores e derrotas.

$\mathrm{Na}$ antologia, inúmeros são os poemas selecionados que partilham esse traço - ratificando, decerto, um traço geral da poesia contemporânea, mas também um gosto do antologista. Há, claro, infinitos modos de "fazer metapoesia". Vejam-se exemplos em Paulo Henriques Britto ("O funâmbulo", p. 232 [de Trovar claro, 1997]), Nelson Ascher ("Homecoming”, p. 33 [de Parte alguma, 2005]), Carlito Azevedo ("Vieira da Silva”, p. 52 [de Sublunar, 2001]), Eucanaã Ferraz (“Uma coisa casa”, p. 194 [de Rua do mundo, 2004]), Julio Castañon Guimarães ("Dos estudos de objeto e ver", p. 130 [de Práticas de extravio, 2003]), Contador Borges ("Ardor maior", p. 89 [de $O$ reino da pele, 2003]) etc. 
Antonio Cicero, por exemplo, em "Merde de poète" (p. 144 [de A cidade e os livros, 2002]), saindo de sua habitual elegância, destila, sardônico: “Quem gosta de poesia 'visceral', / ou seja, porca, preguiçosa, lerda, / que vá ao fundo e seja literal, / pedindo ao poeta, em vez de poemas, merda". 0 toque de humor vem da ambivalência do "visceral", que, literalmente, refere-se a "entranhas", mas, figuradamente, àquilo que quer ser "radical". Também o título afrancesado contrasta com a crueza do "conteúdo" do poema, cujas rimas fortes fixam, ironicamente, a visceralidade do poema que ironiza poéticas viscerais.

Nessa pauta do espanto também investe Ricardo Aleixo, com o belíssimo "Paupéria revisitada" (p. 18 [de Máquina zero, 2003]), título que remete de imediato a Torquato Neto:

Putas, como os deuses, vendem quando dão.

Poetas, não.

Policiais e pistoleiros vendem segurança (isto é, vingança ou proteção).

Poetas se gabam do limbo, do veto do censor, do exílio, da vaia e do dinheiro não). Poesia é pão (para o espírito, se diz), mas atenção:

o padeiro da esquina balofa vive do que faz; o mais fino poeta, não. Poetas dão de graça o ar de sua graça (e ainda troçam - na companhia das traças de tal "nobre condição"). Pastores e padres vendem 
lotes no céu

à prestação.

Políticos compram \&

(se) vendem

na primeira ocasião.

Poetas (posto que vivem

de brisa) fazem do No, thanks

seu refrão.

Aleixo fala do lugar historicamente problemático do poeta na sociedade: putas, policiais, pistoleiros, pastores, padres, políticos, todos compõem uma singular "família do p" e todos (se) vendem algo. 0 poeta, no entanto, como diz uma canção, não se amarra em dinheiro não. A visível ironia em relação à situação precária do artista em todo o poema se extrema na afirmação de que poetas "vivem / de brisa", ou seja, naturalmente e na miséria. 0 complexo poema, entre troças e traças, permite e pede leituras igualmente mais amplas, o que não cabe aqui.

Já Manoel de Barros aposta numa concepção algo ilógica de poesia, se amparando nas falas casuais e imprevisíveis da criança para modelar um mundo de cuja razão e sentido as palavras não dariam conta: "As palavras continuam com seus deslimites" (p. 72 [de Retrato do artista quando coisa, 1998]), "Há um comportamento de eternidade nos caramujos" (p. 72 [de Tratado geral das grandezas do ínfimo, 2001]), "Uso a palavra para compor meus silêncios" (p. 73 [de Memórias inventadas: a infância, 2003]). A repetição dessa concepção e dessa modelagem vai, contudo, esvaziar exatamente o impacto de surpresa que a poesia do pantaneiro deseja produzir. Os incessantes disparates — fruto da justaposição de sensações (abstratas) e objetos (concretos) e de real e fantasia - acabam cansando.

Curiosamente, um verso de Claudio Willer que encerra a antologia de Costa Pinto diz exatamente que "o poema é despreocupação" ("Poética", p. 382 [de Estranhas experiências, 2004]). Longe de advogar por poe- 
mas engajados ou quejandos, o fato, deveras preocupante, é justamente o brutal excesso de poemas metapoéticos, como se os atuais poetas não tivessem - além da palavra como musa - todo um mundo sobre o qual, em versos, pensar.

\section{Intertextualidade}

Uma das formas em que a metapoesia se faz é pela intensa rede intertextual, ora mais ora menos explícita. Os poetas parecem narcisicamente desejar não só exporem as armas que terçam, isto é, o "paideuma" que os constitui, mas, por extensão, exibirem exatamente o repertório que carregam. Fica uma sensação de que para alcançar um "sentido mais puro para as palavras da tribo" é fundamental citar a própria tribo para, quem sabe, passar a pertencer a ela. Na antologia, e nisso ela de fato representa uma tendência forte do cenário poético, há muitos poetas e poemas que participam desse jogo de citações, como os instigantes "Vinte anos depois", de Horacio Costa (p. 159 [de Quadragésimo, 1999]) e "Caixa de ferramentas”, de Augusto Massi (p. 265 [de Negativo, 1990]).

Nas terzas rimas de "Renga em New York" (p. 106 [de Crisantempo, 1998]), a erudição de Haroldo de Campos se faz ver nas referências a, entre outros, Dante, Zukofsky, Lorca, Maiakóvski, Sousândrade, Milton, Blake, Isadora Duncan, Iessiênin, Hart Crane, Cummings, Magritte.

Marcos Siscar intitula um de seus poemas “A Eugenio Montale" (p. 344 [de A terra inculta, 2003]), com isso indicando e solicitando ao leitor que considere essa alusão ao ler o que se seguirá.

Sergio Cohn, em "Ars poética” (p. 147 [de Horizonte de eventos, 2002]), registra que "Yeats viu" e que "Pessoa disse", buscando amparo e cumplicidade dos cânones.

Em procedimento corriqueiro entre certo grupo de poetas, Age de Carvalho abre um de seus poemas com uma epígrafe, no caso, de Paul Celan - e sem tradução - , como que fornecendo de antemão uma chave de leitura para as imagens herméticas que se sucedem ("Triste-triste", 
p. 124 [de Caveira 41, 2003]).

Em dois poemas da antologia, Frederico Barbosa lança mão do expediente da alusão: em "Poesia e porrada” (p. 63 [de Contracorrente, 2000]), elabora uma estrofe de pura citação: “'estou farto do lirismo comedido' / 'fera para a beleza disso' / 'te escrevo fezes' / 'mas ainda não é poesia'” - trechos mais ou menos conhecidos dos bastante conhecidos Manuel Bandeira, Álvaro de Campos, João Cabral de Melo Neto e Carlos Drummond de Andrade; os recifenses (feito Frederico) Bandeira e Cabral retornam no belo "Vocação do Recife", agora ao lado de [Frei] Caneca, Clarice [Lispector] e Sebastião [Uchoa Leite], para afirmar a vocação histórica, afirmativa e combativa, dos artistas e da capital de Pernambuco.

Por fim, ainda, deve-se mencionar o uso hiperbólico do recurso da citação no quase épico "Fragmentos da ode abissal" (p. 217 [de Eles devem ter visto o caos, 1998]), de Afonso Henriques Neto em que

(...) o dna de

carlitos dança um tango operístico-surrealista com beckett

[artaud bohr

\& lênin \& nijinski ou pessoa a telefonar pra joyce \& dada \& borges eliot mann lorca \& picasso a grafitar bigodes e átomos no

[duchamp

poparteando warhol beatles dylan elvis stones a stravinskarem cage parker caruso enquanto eisenstein refilma hiroxima fellini godard welles glauber maio 68 mais drummond valéry corbusier \& tv \& dean \& rosa

\& che \& pelé \& marilyn \& garbo \& delírio \& caos internetização de um espasmo aéreo e redondo brechtfreudfoucaultsartrebartheskafkadeleuzeeinstein potência a cintilar o carvão do Grande Estrondo 
Para Marleide Lima, nesse poema Afonso Henriques utiliza "alguns procedimentos surrealistas como forma de experimentar a liberdade alucinada da linguagem e a ruptura de fronteiras", assim como "imagens deslocadas e díspares que desorientam o leitor acostumado a uma organização racional" (LIMA, 2010). 0 psicodelismo do fragmento encontra seu paroxismo na "fusão" dos oito nomes finais, mimetizando o "Grande Estrondo" que já vinha se anunciando na profusão entre caótica e lógica das alusões. Se toda citação é uma metáfora, como quer Compagnon ${ }^{3}$, então, mais uma vez, vai caber ao leitor - se entender por bem - o esforço de decodificar o porquê de cada citação (logo, cada metáfora), seja de um trecho, seja literalmente de um nome.

Em $A$ angústia da influência - uma teoria da poesia, Harold Bloom (1991), firmado numa genealogia nietzschiana e, sobretudo, freudiana, discorre sobre as relações de cunho edipiano entre o poeta jovem, efebo, fraco, "filho", que, em direção à própria autonomia, deve se libertar do poeta forte, do poeta pai, do poeta canonizado. A essa libertação Bloom nomeia desapropriação ou desleitura e para ela propõe seis tipos de atuação ou "movimentos de desleitura" ou, ainda, "razões revisionárias". Para Bloom, o pior que pode acontecer a um poeta é sacralizar a obra do poeta admirado, tornar-se subserviente e incapaz de reação, ofuscado pela força do outro do qual retira o alimento para a própria fraqueza, qual parasita. Daí ter buscado em Kierkegaard a imagem da ruptura que faz crescer: "Quando duas pessoas se apaixonam, e começam a sentir que foram feitas uma para a outra, então é hora de romper, pois ao prosseguirem não têm nada a ganhar, e tudo a perder" (p. 64). A ideia central bloomiana é que os textos existem em relação, e a possibilidade de estabelecer valores, linhagens, disputas, forças é sempre relacional: “ 0

\footnotetext{
3 “Toda citação é ainda - em si mesma ou por acréscimo? - uma metáfora. Toda definição da metáfora conviria também à citação; a de Fontanier, por exemplo: 'Apresentar uma ideia sob o signo de uma outra ideia mais surpreendente ou mais conhecida, que, aliás, não se liga à primeira por nenhum outro laço a não ser o de uma certa conformidade ou analogia'"' (Compagnon, 1996, p. 15.)
} 
significado de um poema só pode mesmo ser um poema: outro poema — algum outro poema, diferente de si. E também não qualquer poema, escolhido de uma maneira totalmente arbitrária, mas algum poema essencial e de um precursor indubitável, mesmo que o efebo jamais tenha lido esse poema" (p. 107). Saber ler, portanto, o jogo de relações que se trava na história da poesia é tarefa de uma crítica também forte, que cria seu paideuma e o coloca em conflito. Esta crítica deverá ter "a arte de descobrir os caminhos secretos levando de poema a poema” (p. 134). Se o poeta precursor possui, per si, a prioridade (natural) e a autoridade (espiritual), o poeta posterior possui o espaço contemporâneo da atuação. Ele age contra a paixão, o amor, a admiração, a sublimação, o respeito: o poeta, para ser forte, deve agir justamente contra a canonização que congela, correndo, no entanto, o risco de, vencedor, tomar seu lugar no panteão.

\section{Drummond}

Nesse sentido, a antologia de Costa Pinto vem confirmar a supremacia da figura de Drummond junto aos poetas brasileiros, supremacia que aparece sob muitos matizes em inúmeros poemas, como em Augusto Massi, Frederico Barbosa, Afonso Henriques Neto, Carlito Azevedo etc.

Em Adriano Espínola, o poema "Sentimento do mundo" (que abre o livro homônimo, de 1940) é revisitado em "O prego" (p. 190 [de Praia provisória, 2006]): “o que mais dói / não é o retrato / na parede /// mas o prego ali / cravado / persistente /// no centro da / mancha / do quadro au- / sente", em que a quebra da palavra final desvela o sentimento da ausência que o prego fixa, em forma de mancha.

Armando Freitas Filho, sabido entusiasta da poesia do itabirano (com a qual só concorre, para ele, a força fantasmática da poesia de Ana C.), no belo "Palavra-chave" (p. 221 [de Numeral/Nominal, 2003]), traz como epígrafe o célebre trecho de "Procura da poesia" que termina com a pergunta "Trouxeste a chave”, para responder logo no primeiro verso: “Esta chave não é de 
puro ferro" - glosando, uma vez mais, o perfil que de si se fez o poeta de "Confidência do itabirano": "Por isso sou triste, orgulhoso: de ferro".

Já a intrépida iconoclastia de Waly Salomão vai se apropriar da obra de Drummond para ironizar, sem disfarces, críticos e teóricos que se dedicam a interpretar a poesia do gauche mais estudado no país pelos diz Waly - "exércitos da hermenêutica": “(...) Fulano de tal situa sua poesia entre o símbolo e alegoria / e beltrano vislumbra nela o princípio-corrosão / e sicrano percebe uma poética do risco; / enquanto este escrutina a técnica da palavra-puxa-palavra / aquele outro detecta uma estilística da repetição". Waly enfileira, bem informado, cinco estudos importantes acerca da obra de Drummond (de Alfredo Bosi, Luiz Costa Lima, Iumna Maria Simon, Othon Moacyr Garcia e Gilberto Mendonça Teles), engrossando o coro de artistas que entendem - por motivos díspares e em contextos múltiplos - que a crítica não deve tocar na poesia (como canta o amigo Caetano em "Ele me deu um beijo na boca", de Cores, nomes, 1982). 0 próprio Drummond contribuiu para essa confusão, como se a crítica fosse inimiga da criação, com seu "Exorcismo" - embora esse poema, publicado no Jornal do Brasil em 12 de abril de 1975, tivesse como alvo a insípida voga estruturalista que tomara conta de certas universidades: "Das aparições de Chomsky, de Mehler, de Perchonock / De Saussure, Cassirer, Troubetzkoy, Althusser / De Zolkiewsky, Jacobson, Barthes, Derrida, Todorov / De Greimas, Fodor, Chao, Lacan et caterva / Libera nos, Domine" (Andrade, 1992, p. 862). A concepção que o baiano externa no poema "Ler Drummond" (p. 334 [de Pescados vivos, 2004]) é, na verdade, romântica, para não dizer ingênua, ao achar que o poema (ou a obra) de Drummond (ou de qualquer poeta) permaneça "qual rútilo e incorruptível diamante" e "imune" aos tais assaltos. Há uma glorificação épica, bem ao estilo Waly, da poesia e da arte, e uma demonização (também épica!) do gesto interpretativo.

\section{Formas}


Considerada a antologia em foco, são hegemônicos os versos brancos e livres. Privilegia-se o ritmo (mesmo porque há ritmo em tudo), mas fora das chamadas formas fixas. 0 soneto aparece - com excelência em seis poetas: Nelson Ascher, Alexei Bueno, Antonio Cicero, Reynaldo Damazio, Paulo Henriques Britto e Glauco Mattoso, recordista mundial absoluto no gênero.

Experiências visuais há nos poemas de Augusto de Campos, Arnaldo Antunes, João Bandeira, Frederico Barbosa, Waly Salomão, Zuca Sardan e Julio Castañon Guimarães.

Na contramão da tendência contemporânea, Antonio Fernando de Franceschi traz excelentes poemas que "parodiam" formas clássicas, como o belíssimo "Canzione" ("de nada vale amor que mero / ocupa verso e rima: se vero / não poupa: se raro preocupa / amor que vale arde e machuca”, p. 184 [de Cinco formas clássicas, 2002]).

\title{
7. Cotidiano
}

Outra força da poesia desse início de século é a eleição do cotidiano como matéria contínua para a criação. É um cotidiano completamente esvaziado de lances grandiosos ou heroicos; ao contrário, o olhar dessa época prefere os gestos sutis, mínimos, que, em princípio, escapam aos olhares da urbe, casos de Manoel de Barros, Adélia Prado, Francisco Alvim, Tarso de Melo, entre tantos.

Nesse contexto, o silencioso mundo das coisas e dos objetos é captado pelos sentidos do poeta, que vai desentranhar do aparente nada o movimento de algo, como no delicado e duro "Território" (p. 350 [2004) de Eduardo Sterzi:

\author{
Mesmo o pó dorme, a esta hora, \\ desprezado \\ pelo sol. Podes \\ vagar tranquilo
}




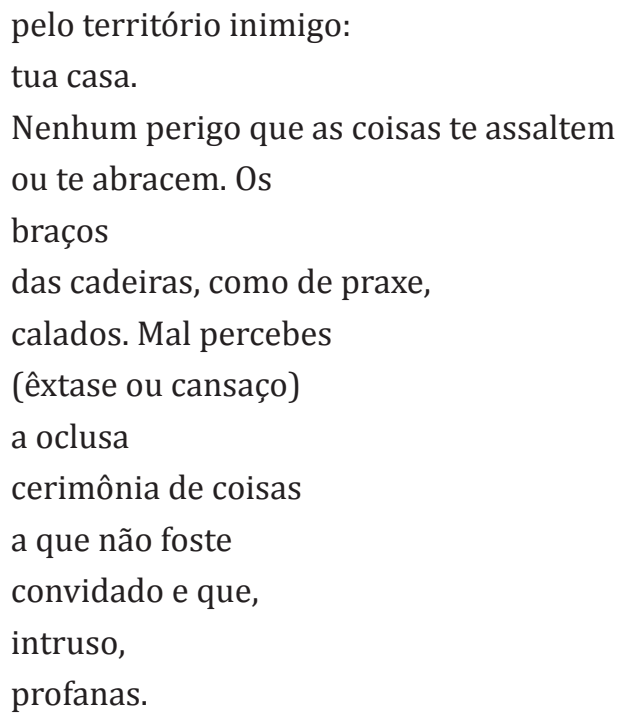

Esse mundo silencioso dos objetos, das coisas, do inanimado acaba por constituir autênticas poéticas do olhar, ou seja, como vejo o meu redor e como me aproprio dele (PEDROSA, 2011).

\section{Morte}

A tópica clássica da morte (a morte mesma, e não a questão "vizinha" da transitoriedade e da finitude - também presente) aparece com refinado humor em Alberto Martins, com resignada gravidade em Ferreira Gullar e com simulada indiferença em Paulo Henriques Britto:

"Enterro": "(...) - que o morto sempre comparece / aos seus últimos encontros, /// sob a chuva / ou no engarrafamento de um sonho. /(...)/ a partir de agora, o morto só acorda / quando a própria vida o incomoda" (p. 259 [de Cais, 2002]).

"Nova concepção da morte": "Como ia morrer, foi-lhe dado o aviso / na carne, como sempre ocorre aos seres vivos; /// um aviso, um si- 
nal, que não lhe veio de fora, / mas do fundo do corpo, onde a morte mora, /// ou dizendo melhor, onde ela circula / como a eletricidade ou o medo, na medula $/(. .$.$) / E é por essa razão que, quando um homem$ morre, /// alguém que esteja perto e que apure o ouvido, / certamente ouvirá, como estranho alarido, /// o jorrar ao revés da vida que vivera / até tornar-se treva o que foi primavera" (p. 213, [de Muitas vozes, 1999]).

“Três epifanias triviais” (II): “(...) Tudo que pensa passa. Permanece / a alvenaria do mundo, o que pesa. /(...). As testemunhas cegas da existência, / sempre a te olhar sem que você se importe, / vão assistir sem compaixão nem ânsia, / com a mais absoluta indiferença, / quando chegar a hora, a tua morte. / (Não que isso tenha a mínima importância.)” (p. 234 [de Macau, 2003]).

Indiferença, humor, gravidade: para a morte, e os poemas parecem mostrar isso, o que o sujeito pensa e sente não tem lá tanta importância. Percebe-se, em resposta à incontornabilidade da morte, uma espécie de esvaziamento do caráter metafísico da finitude.

\section{Humor}

O humor, que anda escasso no quadro geral da poesia contemporânea, na antologia até que comparece com alguma frequência, possivelmente como piscadela do antologista para deleite de um público leitor mais amplo. É o caso de poemas, embora tematicamente bem distintos, que se irmanam pelo recurso ao cômico, em sentido lato. Em "Ponto morto" (p. 267 [de A vida errada, 2001], de Augusto Massi, por exemplo, o humor se revela melancólico, com o sujeito enredado em desencontros e histórias familiares - a expressão "a vida parou”, em pleno trânsito engarrafado, lembra de imediato o "Cota zero" de Drummond:

A minha primeira mulher

se divorciou do terceiro marido. 
SALGUEIRO, W. A poesia brasileira lida numa antologia: exercícios de solidão
A minha segunda mulher
acabou casando com a melhor amiga dela.
A terceira (seria a quarta?)
detesta os filhos do meu primeiro casamento.
Estes, por sua vez, não suportam os filhos
do terceiro casamento da minha primeira mulher.
Confesso que guardo afeto pelas minhas ex-sogras.
Estava sozinho
quando um de meus filhos acenou para mim no
meio do engarrafamento.
A memória demorou para engatar seu nome.
Por segundos, a vida parou, em ponto morto.

Já em "Ridículos" (p. 169 [de Nu entre nuvens, 2001]), de Reynaldo Damazio, a partir de associações sonoras, que ganham o ápice no apontamento anagramático entre "idílio" e "ridículo", o corpo - com seus desejos, cios e vícios - é ironizado em sua pequenez, em perspectiva antirromântica:
é voraz
o vazio
da besta
no cio
é mordaz
o sorriso
do palhaço
sem circo
é fugaz
o pavio
desse corpo
ímpio 


\author{
o círculo \\ do desejo \\ o vício \\ daquele \\ beijo \\ o idílio e \\ o ridículo \\ dão no mesmo
}

$\mathrm{Na}$ antologia de Costa Pinto, há poetas que notoriamente se valem com frequência do tom humorístico: Francisco Alvim, Chacal, Glauco Mattoso, Zuca Sardan são alguns exemplos. Desse último, comentará o antologista: "As personagens de sua poesia parecem saídas de um filme de pastelão dos irmãos Marx ou de contos de fadas narrados por um locutor alucinado" (p. 142). De Chacal, diz ter uma "poética desinflada, espontânea, jocosa" (p. 137) e de Glauco destaca o vínculo entre "insurreição moral e irreverência formal" (p. 277). Nicolas Behr — citado no comentário a Chico Alvim por causa da "dicção desinflada" de ambos - é um poeta bastante conhecido por seus poemas críticos e engraçados (assim como Tião Nunes) e é uma das ausências mais flagrantes na coletânea.

\title{
10. Cidade
}

Desde há muito, a cidade se tornou um dos ambientes preferidos da literatura. Há inúmeros estudos que se dedicam a investigar sua importância, sobretudo a partir da dialética entre multidão e solidão - recordem-se, por exemplo, as obras oitocentistas de Charles Baudelaire e de Cesário Verde, ou de Machado de Assis e de Edgar Allan Poe, e os estudos de Walter Benjamin (1994) e de Renato Cordeiro Gomes (1994). 
Aqui, também a cidade se exibe "paisagem urbana como tópico da lírica moderna" (p. 17), diz Costa Pinto ao comentar poemas de Sérgio Alcides, autor de um livro exatamente intitulado $O$ ar das cidades [2000]. Está na antologia o célebre "cidade/city/cité" (Vivavaia, 1979), de Augusto de Campos.

O sentimento contemporâneo em relação à cidade tornada megametrópole inclui aversão, repúdio, ruptura:

\author{
Por que, se não há neste \\ subarremedo de urbe re- \\ fugado, ou melhor, púbere- \\ caduco clone agreste
} do urbano, algo que preste, e embora, como em úbere dum rato, aqui se incumbe repetidamente a peste

\author{
chamo ainda, feito abutre \\ doentio que, sem cessar, \\ vomita mas se nutre do \\ seu vômito, apesar \\ de ser (ou porque é) pútrido, \\ São Paulo de meu lar?
}

No sinuoso soneto "São Paulo" (p. 31 [de Parte alguma, 2005]), de Nelson Ascher, acima, a pergunta "Por que chamo ainda São Paulo de meu lar?" se contamina - para que seja formulada - de "caduco", "rato", "peste”, “abutre”, "vômito”, "pútrido”, evidenciando a relação conflituosa entre o cidadão e seu habitat.

\title{
11. Violência
}

Uma ausência significativa é a de problematizações relacionadas a 
manifestações da violência, em especial no Brasil. Catástrofes ou dramas coletivos praticamente inexistem nas duas centenas de poemas. Em seu lugar, sobressaem os dramas individuais, em que às vezes, de forma tênue, tangencia-se a miséria social.

Tal escassez de poemas - que, de alguma forma, tragam os inúmeros conflitos que o homem enfrenta na vida real, como fome, preconceito, violências de toda ordem - não é idiossincrasia do antologista. Esse quadro de escassez há de se repetir em outras antologias, assim como no conjunto da produção contemporânea.

Parece que, há algum tempo, a expressão poética tem privilegiado os problemas individuais (corpo, cotidiano pessoal) e os malabarismos autotélicos da palavra (metapoesia, citações lúdicas). Nesse contexto, vale sempre destacar as vozes dissonantes, que buscam articular, lembrando Adorno, lírica e sociedade. Na antologia em foco, apenas três poemas falam, sem rebuços, de questões em que conflitos sociais se declaram: em Claudia Roquette-Pinto aparece a violência urbana; em Ricardo Corona o imperialismo norte-americano; em Paulo Ferraz a luta de classes. Sobre o longo poema deste último, "De uma crítica publicada num suplemento cultural de domingo", escrevi recentemente um artigo (SALGUEIRO, 2013); sobre os outros dois, comento a seguir.

No âmbito acadêmico, ganhou notoriedade o poema "Sítio" (p. 323 [de Margem de manobra, 2005]), de Claudia Roquette-Pinto, publicado primeiramente na revista Inimigo rumor, em 2001, dada a repercussão bastante positiva de um ensaio sobre ele, de autoria de Iumna Maria Simon (2008a) ${ }^{4}$. Antes desse artigo, contudo, Marcelo Sandmann (2002) publicou um ensaio também acerca do poema. E, ainda, Paulo Henriques Britto (2010) ampliou as considerações de ambos em seu livro Cláudia Roquette-Pinto, para a Coleção Ciranda da Poesia. Os três ensaios, portanto, afora outras referências esparsas, reforçam a afirmação de Paulo Henriques que "Sítio" será "lido no futuro como um dos poemas centrais

${ }^{4}$ Com o mesmo título, publicado em Pedrosa; Alves, 2008; e com o título "Poema e bala perdida", publicado em Estudos de Literatura Brasileira Contemporânea (Simon, 2008b). 
da época em que foi escrito" (p. 34):

O morro está pegando fogo.

0 ar incômodo, grosso,

faz do menor movimento um esforço,

como andar sob outra atmosfera,

entre panos úmidos, mudos,

num caldo sujo de claras em neve

Os carros, no viaduto,

engatam sua centopeia:

olhos acesos, suor de diesel,

ruído motor, desespero surdo.

O sol devia estar se pondo, agora

- mas como confirmar sua trajetória

debaixo desta cúpula de pó,

este céu invertido?

Olhar o mar não traz nenhum consolo

(se ele é um cachorro imenso, trêmulo,

vomitando uma espuma de bile,

e vem acabar de morrer na nossa porta).

Uma penugem antagonista

deitou nas folhas dos crisântemos

e vai escurecendo, dia-a-dia,

os olhos das margaridas,

o coração das rosas.

De madrugada,

muda na caixa refrigerada,

a carga de agulhas cai queimando

tímpanos, pálpebras:

o menino brincando na varanda.

Dizem que ele não percebeu.

De que outro modo poderia ainda

ter virado o rosto: "Pai!

acho que um bicho me mordeu!" assim 
que a bala varou sua cabeça?

As três eficazes leituras valorizam, evidentemente, o engenho do poema que - para tratar, sem espetacularizar, de uma tragédia urbana e, sobretudo, tendo uma criança como vítima - funciona quase como um conto, sobrepondo camadas de perspectivas, de que a trágica fala do menino entre itálicos que a rodeiam seria um exemplo máximo. Todos os ensaístas atentam para as conexões entre a forma e a história, mas Iumna é a mais incisiva: "O arranjo formal atesta que a poesia que oferece proteção por imagens falha diante da bala perdida e precisa empreender uma volta à referência, mesmo que com isso se rompa o ritmo, a imagética e o timbre da escrita” (p. 151). Chama a atenção a exótica associação do verso 19, "penugem antagonista", cujo adjetivo, no contexto em que aparece, faz recordar considerações de Theodor Adorno acerca do termo: em Teoria estética, afirma que "os antagonismos não resolvidos da realidade retornam às obras de arte como os problemas imanentes da sua forma" (2008, p. 18); em "Palestra sobre lírica e sociedade”, diz: "a configuração lírica é sempre, também, a expressão subjetiva de um antagonismo social. Mas como o mundo objetivo, que produz a lírica, é um mundo em si antagonístico, o conceito de lírica não se esgota na expressão da subjetividade, à qual a linguagem confere objetividade" (2003, p. 76). Com clareza, Jaime Ginzburg esclarece o pensamento adorniano: "por antagonismos formais devemos entender situações de incorporação à forma artística de um impasse, de uma negatividade constitutiva, em que a forma de uma obra, em termos estilísticos e historiográficos, entra em confronto com as tendências hegemônicas de produção cultural, bem como com os valores ideológicos dominantes. Conflitos e lutas sociais ecoam e deixam marcas nas obras” (2012, p. 135). No poema, muitos elementos contribuem - para além da óbvia "penugem antagonista” - para que uma interpretação à luz da história se faça. Listá-los 
seria quase parafrasear as três ótimas leituras referidas. Aponte-se (seguindo a fala de Britto em relação à análise de Sandmann) a polissemia do título, que encontra guarida no poema: "sítio" pode ser, e no poema é, "lugar", "chácara”, “cerco” e, também, aciona a expressão "estado de sítio". Desde o título, dirá Sandmann que "todo o texto, com sua saturação de tensões, é um preâmbulo para o impacto da última cena: (...) A bala terá certamente sido disparada no primeiro verso, para chegar a seu alvo no verso derradeiro, depois de uma distensão temporal impressionante e uma trajetória que agrega/desagrega todo o complexo de espaços (naturais e sociais) da grande metrópole" (p. 86). Entre o aprazível bucólico de um sítio-chácara e um contexto de intervenção do Estado no cotidiano dos cidadãos, entre a paz e a brutalidade, transita o chocante poema.

Em “Aguafuerte porteña” (p. 151 [de Corpo sutil, 2005]), de Ricardo Corona, a dedicatória aos ativistas Noam Chomsky e Michael Moore, críticos da american way of life, já antecipa o tom combativo e contundente do poema:

América,

ao norte e sob um sol falso,

teus filhos se afastam

do aroma dos prados.

Os mesmos filhos

que atuaram contra a desobediência civil

de Thoreau

e fazem da democracia

um inimigo invisível.

Os mesmos

que têm a melanina impermista 
e detestam semente

de melancia.

São eles, América,

os benevolentes

que cobram somente os juros

da dívida do terceiro mundo.

São eles, América,

os beneficiários

que cumprem religiosamente a sua parte

na permuta de cifra bélica.

Os mesmos

que sacodem bandeiras

quando tropas ultrapassam fronteiras

e nutrem

um orgulho cívico

para cada medalha espetada no peito

das baixas

devolvidas à vida civil.

América, são eles,

os mesmos de sempre,

que, a cada estação,

reimprimem a cicatriz neo não

e reorganizam etnias

em açougues.

São eles, América,

os adeptos da assepsia

que os deixa menos imunes

ao terror químico.

São eles, América,

os jogadores de cassino 


$$
\begin{aligned}
& \text { que inflam suas bolsas escrotais } \\
& \text { com o sobe-e-desce da Nasdaq } \\
& \text { - o mundo que se foda } \\
& \text { com seus bolsões de pobreza. }
\end{aligned}
$$

São eles,

sim, são eles, América,

os mesmos

que têm a maior indústria de entretenimento

do planeta

e representam grande parte da tristeza

existente neste

mundo.

Não, América,

não são os que Walt Whitman separou

feito as folhas da relva

e os fez americanos.

Os americanos estão dentro da América

- ao sul, ao norte e ao centro -

feito o anagrama

"Iracema".

Este é um poema que, a despeito das muitas citações incorporadas, parece não se deslumbrar com jogos verbais autotélicos. Ao contrário, a gama de autores (desde a dedicatória) e textos que agencia desenha um quadro ideológico relativamente transparente: é um poema que se rebela contra o imperialismo norte-americano. 0 próprio alcance da noção de "América" está em todo o poema: diferentemente do que os estadunidenses propagam, a América é todo o continente americano ("ao sul, ao norte e ao centro") e não apenas um país, os Estados Unidos. Não se trata de um libelo juvenil contra os ianques, contra a pátria de Whitman, 
nem tampouco um engrandecimento ufanista da pátria de Alencar. É, antes, um alerta quanto à postura invasiva, neocolonialista, autoritária que sustenta a política norte-americana, com apoio da maioria da população.

0 título do poema recupera título de obra de ensaios do argentino Roberto Arlt, que vai, justamente, falar, entre outros assuntos, de problemas da capital portenha. Água-forte é uma técnica de gravura que utiliza ácido; por extensão, o termo passou a significar um pensamento forte, contundente. Thoreau e Whitman são dois escritores (filósofo, poeta) norte-americanos que poderiam ser irmanados sob o adjetivo "libertários" - o poeta brasileiro, é claro, com eles se identifica. Além desse espírito libertário, de Whitman vai buscar o estilo de poemas longos, declamáveis, retóricos; de Thoreau a ideia central de "desobediência civil", antigovernista.

0 conflito étnico que aqui e ali se disfarça encontra no poema um disfarce semelhante na estrofe 3: brancos são os "mesmos / que têm a melanina impermista / e detestam semente / de melancia", ou seja, os negros. A opressão em direção ao terceiro mundo e a fachada e alienação religiosa são referidas nas estrofes seguintes (4 e 5). A estrofe 6, a mais longa, fala do "orgulho cívico" com as mortes que ocorrem em guerras "quando tropas ultrapassam fronteiras". A estrofe 7 não mede palavras, acusando esse "eles", os "mesmos" que se locupletam da miséria alheia, que inflam "suas bolsas escrotais" com as variações da bolsa Nasdaq e "o mundo que se foda / com seus bolsões de pobreza". A estrofe 8 cita, ao avesso, trecho de canção de Caetano Veloso, trocando a apologia de "os americanos representam boa parte da alegria existente neste mundo" do baiano (que ainda não compusera "Base de Guantánamo") por "grande parte da tristeza existente neste mundo". A indústria cultural é planetária, está em todo lugar, mas é evidente o esforço e as ações de expansão da cultura norte-americana para o resto do mundo. A última estrofe, que parece em princípio um cansaço, um grand-finale com metáfora romântica, pode, no entanto, ser lida com mais vigor, acompanhando a força do poema como um todo. Nesse caso, mais que uma idealização, "Iracema” 
seria a pujança do híbrido, daquilo que resiste aos incessantes ataques etnocêntricos dos Estados Unidos, escudados, ainda, numa hegemonia política e econômica, ameaçada, é certo, por outras forças (seja que querem o seu lugar, seja que não querem ninguém nesse lugar).

\section{Conclusão}

Como toda antologia que se preze, o que se tem em vista é um panorama, horizontal, de um momento - e nisso ela atende bem ao propósito. Ela mostra a convivência de gerações; a forte presença de poemas herméticos e metalinguísticos; a potência do recurso da intertextualidade e, nela, a supremacia da figura de Drummond; a predominância de versos brancos e livres, o que não exclui o experimentalismo visual e o retorno reinventado a formas tradicionais; uma predileção pela "narrativa" de eventos do cotidiano; o tema fantasmático da morte; o recurso, contido, de um humor leve, próximo da ironia; a cidade como lugar de sedução e de errância.

Além desses aspectos, outros poderiam ser indicados, como [a] uma poética do corpo (não necessariamente erótico), vista por exemplo em Josely Vianna Baptista ou Arnaldo Antunes; [b] a constante referência a animais, como no engenhoso poema "g", de Micheliny Verunschk, em que gato e letra se confundem, ou no expressionista “O grito”, de Donizete Galvão, em que a agonia do porco não impede o tornar-se chouriço; [c] um grave sentimento metafísico, que impregna obras como as de Alexei Bueno e Adélia Prado; [d] uma atração compulsiva em falar do silêncio, como em Dora Ribeiro e Ronald Polito.

Considerando a Antologia comentada da poesia brasileira do século 21, com suas dezenas de poemas e poetas, uma espécie de microcosmo - bastante representativo - da poesia brasileira em curso, podemos inferir que, em linhas gerais, trata-se nossa poesia contemporânea de [a] uma produção solipsista, centrada nos acontecimentos singulares da vida do sujeito que escreve - ensimesmada; de [b] uma produção in- 
diferente a questões de cunho político, social, coletivo - desengajada; de [c] uma produção em que rareia a presença crítica do humor (quando muito, dá-se a ver certa ambivalência irônica) — desengraçada; de [d] uma produção que, além de se encastelar em alusões a herméticos acontecimentos da vida do autor, excede em jogos e torneios metapoéticos - autotélica. Na contracorrente desses traços, aqui e ali aparecem poemas e poetas em que o interesse pelo outro se impõe como força e tema.

Por exemplo, no poema "História das demolições" (p. 156 [Folha de São Paulo, 2004]), Fabrício Corsaletti não trata de uma demolição em particular, mas, alegoricamente, fala da ação categórica do tempo como elemento de esquecimento:
A história das demolições
a história trágica das demolições
não acontece como no cinema
a vida não tem trilha sonora
as paredes caem silenciosamente
(no máximo a pancada dos martelos)
o chão varrido fica melhor
(o passado não voltará no ladrilho novo)
lembrar o que quer que seja é inútil
as imagens da memória são ruins
o que ficasse em nós seria a esperança
mas o que existe não exige lembrança
o que morreu está definitivamente morto
não há sequer a vontade de chorá-lo
o luto mesmo é impossível

Ecoa no poema um pensamento benjaminiano acerca de rastro, ruína e história. As ruínas dão a ver o que se foi - são a marca melancólica de um tempo de outrora. 0 presente se impõe: "o chão varrido fica melhor / (o passado não voltará no ladrilho novo)”. A vida real não se estetiza - como no cinema. Mas o poema é também uma vitória da "cultura" 
sobre a "barbárie": a repetição nos versos 1 e 2, o conflito entre cinema e vida e entre som e silêncio, as rimas (esperança / lembrança etc.) e as aliterações, os conceitos apropriados (história, memória, luto), tudo faz do poema aquilo contra o que, de alguma forma, ele investe: o poema é também o mundo.

Na análise que fez de "Sítio", Marcelo Sandmann a certa altura afirma sem rodeios: "Parece haver um descompasso entre a tragédia humana e social em que nos encontramos inseridos e a prática da poesia, como se esses mundos fossem incompatíveis e incomunicáveis. Ou então uma refração dessas questões de forma tão indireta, tão enviesada, tão microscópica, tão elíptica, que surge meio impalpável, mesmo inapreensível para boa parte dos leitores" (p. 87). A sensação que resta, após a leitura da antologia em pauta, é exatamente esta: de descompasso. E não necessariamente por culpa da seleção e dos critérios que nortearam a antologia de Costa Pinto. 0 fato é que aqui, nos poemas da coletânea, ou alhures, a presença de temas ligados à violência, mesmo em sentido lato, é “enviesada, microscópica, elíptica”, enquanto em outras manifestações artísticas (como, por exemplo, na narrativa literária ou no cinema), na mídia impressa e televisiva e, naturalmente, na "vida real", a violência se dá a ver com irrefutável frequência.

Parece haver um temor generalizado por fazer uma poesia que se contamine de história, de reflexões sociais, de algo que lembre "engajamento", conceito e prática que foram expurgados do vocabulário e das atitudes de poetas e cidadãos, cada vez mais ilhados entre quatro vetores: 1) o sujeito importa mais que o coletivo, 2) a solidão que a solidariedade, 3) os meios estéticos autorreferenciais valem mais que uma poesia que leve à reflexão, 4) o efeito e a contemplação valem mais do que qualquer ação. 


\section{Referências bibliográficas}

ADORNO, T. Teoria estética. Tradução: Artur Morão. Lisboa: Edições 70, 2008.

ADORNO, T. Palestra sobre lírica e sociedade. Notas de literatura I. Tradução: Jorge de Almeida. São Paulo: Duas cidades; Ed. 34, 2003, p. 65-89.

ANDRADE, C. D. Exorcismo. Discurso de primavera e algumas sombras. In: Carlos Drummond de Andrade - Poesia e prosa em um volume. 8. ed. Rio de Janeiro: Nova Aguilar, 1992, p. 862.

BENJAMIN, W. Charles Baudelaire um lírico no auge do capitalismo. 2. ed. Trad. José Carlos Martins Barbosa; Hemerson Alves Baptista. Rio de Janeiro: Brasiliense, 1994. (Obras escolhidas, 3).

BLOOM, H. A angústia da influência - uma teoria da poesia. Tradução: Arthur Nestrovski. Rio de Janeiro: Imago, 1991.

BRITTO, P. H. Claudia Roquette-Pinto. Rio de Janeiro: EdUerj, 2010.

COMPAGNON, A. O trabalho da citação. Tradução: Cleonice P. B. Mourão. Belo Horizonte: Editora UFMG, 1996.

GINZBURG, J. Crítica em tempos de violência. São Paulo: Edusp, 2012.

GOMES, R. C. Todas as cidades, a cidade: literatura e experiência urbana. Rio de Janeiro: Rocco, 1994.

LIMA, M. A. Deambulações do olhar: a escrita interartes de Afonso Henriques Neto. Dissertação. UFF, 2010. Disponível em: http://www. bdtd.ndc.uff.br/tde_arquivos/23/TDE-2010-09-15T141642Z-2629/ Publico/Marleide\%20Lima-Dissert.pdf. Acesso em: 26 set. 2013.

PEDROSA, C. Poéticas do olhar na contemporaneidade. Ensaios sobre poesia e contemporaneidade. Niterói: Editora da UFF, 2011, p. 119147. 
PINTO, M. C. Antologia comentada da poesia brasileira do século 21 (org.). São Paulo: Publifolha, 2006.

SALGUEIRO, W. Poesia brasileira do século 21: ensimesmada, desengajada, desengraçada (no entanto, um poema de Paulo Ferraz). Anais Abralic Internacional. Campina Grande: Realize, 2013. v. 1. p. 1-12.

SANDMANN, M. Poesia em estado de sítio. Sebastião, no. 2. São Paulo, 2002, p. 81-87.

SIMON,I.M.Situação deSítio.Novosestudos CEBRAP,SãoPaulo,n.82,novembro de 2008a. Disponível em: http://www.scielo.br/scielo.php?script=sci_arttext\&pid=S0101=33002008000300008-\&lng=en\&nrmiso. Acesso em: 14 out 2013.

SIMON, I. M. Situação de Sítio. PEDROSA, Celia; ALVES, Ida (orgs.). Subjetividades em devir: estudos de poesia moderna e contemporânea. Rio de Janeiro: 7Letras, 2008, p. 133-146.

SIMON, I. M. Poema e bala perdida. Estudos de Literatura Brasileira Contemporânea, no. 32. Brasília, julho-dezembro de 2008b, p. 145159. Disponível em http://www.gelbc.com.br/pdf revista/3211.pdf. Acesso em 14 out. 2013.

TONON, E. A poesia brasileira em suas antologias: tempo e representação. Disponível em: http://dlcv.fflch.usp.br/sites/dlcv.fflch.usp.br/ files/05 10.pdf. Acesso em 17 out. 2012. 